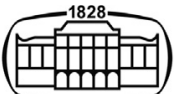

AKADÉMIAI KIADÓ

Developments in Health Sciences

3 (2020) 2, 44-51

DOI:

(c) 2020 The Author(s)

\section{REVIEW ARTICLE}

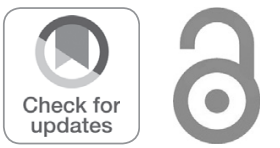

\title{
Brave new world an update on COVID-19 pandemic - A review
}

10.1556/2066.2020.00009

\section{K. GADÓ ${ }^{1 *}$, GY. DOMJÁN ${ }^{1,2}$ and Z.Z. NAGY ${ }^{3,4}$}

\author{
${ }^{1}$ Department of Clinical Studies, Faculty of Health Sciences, Semmelweis University, Budapest, \\ Hungary \\ ${ }^{2}$ Department of Laboratory Medicine, Faculty of Medicine, Semmelweis University, Budapest, \\ Hungary \\ ${ }^{3}$ Department of Ophthalmology, Faculty of Medicine, Semmelweis University, Budapest, Hungary \\ ${ }^{4}$ Department of Clinical Ophthalmology, Faculty of Health Sciences, Semmelweis University, \\ Budapest, Hungary
}

Received: May 26, 2020 • Revised manuscript received: June 10, 2020 • Accepted: July 3, 2020

Published online: November 10, 2020

\begin{abstract}
Epidemics and pandemics have happened throughout the history of mankind. Before the end of the 20th century, scientific progress successfully eradicated several of the pathogens. While no one has to be afraid of smallpox anymore, there are some new pathogens that have never caused human disease before. Coronaviruses are a family of enveloped RNA viruses. In the 21 st century, three of them have caused serious pandemics, including severe acute respiratory syndrome in 2002 and Middle East Respiratory Syndrome in 2012. In 2019 severe acute respiratory syndrome coronavirus 2 (SARS-CoV-2) caused the coronavirus disease-19 (COVID-19) pandemic, which has destroyed hundreds of thousands of lives and continues to rage.
\end{abstract}

\section{KEYWORDS}

COVID-19, thrombotic risk, pandemic, antiviral treatment

\section{INTRODUCTION}

On March 11th, 2020, the World Health Organization (WHO) officially determined that COVID-19 should be characterized as a pandemic [1]. The first confirmed COVID-19 cases were reported in Wuhan, a city in Hubei Province in central China with 11 million inhabitants. Clinical characteristics were very similar to those of viral pneumonia. Analysis of respiratory samples revealed that the pneumonia was caused by a novel coronavirus [2]. The virus was named severe acute respiratory syndrome coronavirus 2 (SARS-CoV-2) and WHO officially named the disease COVID-19.

The outbreak began at seafood and live animal market in Wuhan on December 12, 2019 [3]. It rapidly spread, resulting in an epidemic throughout China, followed by a continuously increasing number of cases in more than 180 countries all over the world. At the time of preparing this manuscript, the World Health Organization had reported 4,990,470 confirmed cases, including 324,990 deaths [4].

Economic, financial, social, psychological, and health aspects of this pandemic hardly can be established yet, but it will definitely have a huge impact on the whole world, and it will be a major challenge to overcome the crisis generated by COVID-19.

\section{Route of the virus}

Coronaviruses are single-strand RNA viruses, the majority of which cause diseases in animals. Six were previously known to cause respiratory diseases in humans, and SARS-CoV-2 became the seventh. It belongs to the family Coronaviridae a large family of viruses prevalent 
in nature. Natural hosts, intermediate hosts, and final hosts of SARS-CoV-2 are not entirely known. According to the complete genome-sequence recognition rates of SARS-CoV and bat coronavirus RaTG13 (SARSr-CoV-RaTG13), it is supposed that the primary host was the bat [5].

Because many of the initially infected patients worked in or visited the Wuhan market, it was supposed that Pangolin and other exotic animals that had been sold in the market were an intermediate host [6]. However, because a connection could not be demonstrated between further cases and the market, the role of the intermediate host has been questioned [7]. There is also evidence supporting the scenario of somebody being infected outside the market and then bringing it there [7]. The point where the virus jumped from animal to human will probably never be revealed, but the connection with the Wuhan market will remain suspicious.

There had been 4,990,470 SARS-CoV-2 cases (including 324,990 deaths and 1,961,385 recoveries) reported when this manuscript was prepared [4], but these figures are expected to increase further, as they are updated daily.

\section{About SARS-CoV-2}

Four structural proteins are essential for virion assembly and infection: the spike (S), membrane (M), envelop (E), and nucleic capsid $(\mathrm{N})$ proteins.

Homotrimers of $S$ proteins constitute the spike, which is on the surface of the virion and facilitates cell entry by binding to a receptor on the target cell and mediating virus-cell fusion. It has been reported that the SARS-CoV-2 spike protein interacts with human ACE2 (angiotensin-converting enzyme 2) to infect human respiratory epithelial cells [8]. Since its discovery in 2000, ACE2 has been found protective in multiple pathophysiological processes, including the alleviation of pathological changes in acute lung injury (ALI) and acute respiratory distress syndrome (ARDS), the inflammatory and fibrotic responses in diseases, and the absorption of neutral amino acids in the intestine as a partner of amino acid transporters [9]. Now ACE2 is thought to be a double-edged sword, as it also acts as a receptor and opens the door for SARS-CoV-2 [10].

\section{Pathogenesis of SARS-CoV-2 infection in humans}

After the virus passed through the nasal and laryngeal mucosa, it enters the lung via the respiratory tract. From the lung, it gets into the bloodstream and causes viremia. After spreading through the peripheral blood, it can attack organs that express ACE2 receptors on their cell surface such as the gastrointestinal tract, skin, lymph nodes, thymus, bone marrow, spleen, liver, kidney, and brain [11]. The number of lymphocytes gradually decreases during the disease's progression, and antibody production can also be decreased. In seriously ill patients, the number of lymphocytes is markedly lowered. An increased level of inflammatory factors such as IL-6 contributes significantly to the aggravation of the disease around 7-14 days after onset.

ACE2 is a crucial component of the renin-angiotensin system (RAS). It antagonizes activation of the classical RAS system and protects against organ damage, thereby playing an important role in hypertension, diabetes, and cardiovascular disease.

ACE2 is also involved in SARS-CoV-2 invasion of the human alveolar epithelial cells [12]. COVID-19 patients with severe pneumonia have a typical acute respiratory distress syndrome (ARDS) pathology in the lung. Though ACE2 normally has a protective effect on this type of acute lung injury ARDS is a disease characterized by high mortality [13]. Histologic studies of COVID-19 pneumonia reveal alveolar spaces with the focal hyaline membrane, pneumocyte proliferation, and metaplastic changes. Signs of virus-induced cytopathy, such as multinucleation and nuclear atypia, are also common. Lymphocytes and macrophages constitute the vast majority of inflammatory cells [14].

\section{Host immune response and immunopathology}

A marked immunological feature of COVID-19 is lymphocytopenia and the reduction of both $\mathrm{T}$ cells and natural killer (NK) cells. The number of NK cells is extremely low in some critically ill patients. As there is no ACE2 expression on lymphocytes, it might be supposed that the disturbed functioning of the immune system is caused by a cytokine storm, not the virus itself.

Endothelium damage is also a typical clinical feature in severe COVID-19 patients. Vasculitis-like manifestations, necrosis of extremities, and thrombosis could be seen in severe COVID-19 patients. Vascular damage may be caused by direct injury of endothelial cells by the virus and may lead to disseminated intravascular coagulation or anti-phospholipid syndrome (APS) [15].

\section{Virus transmission}

Transmission of the SARS-CoV-2 virus occurs mainly by virus-containing air droplets but it can also occur by touching the face after touching virus-contaminated surfaces and by the faecal-oral route. Viability of the virus in air droplets and on different surfaces has been studied. There is an exponential decay in virus titer over time. The half-life in droplets is approximately 1.1-1.2 hours, and it is longer on plastic and stainless steel than on copper and cardboard [16].

Basic Reproduction Number $\left(\mathrm{R}_{0}\right)$ refers to the average amount of secondary infection that patients may produce in a completely susceptible population without intervention [17]. In the case of SARS-CoV-2, this number is 1.5-3.5. However, there are so-called superspreaders that can give the infection to many more, even to hundreds of people. Super spreading depends on the virulence of the virus, on crowded places, on the hygiene and behaviour of the person, and on co-infection with other pathogens [18].

\section{Diagnosis}

Diagnosis is based on clinical findings and demonstration of the virus RNA. Detecting antibodies generated against the virus is also important, but it does not necessarily mean acute disease. Pneumonia can be diagnosed by chest X-ray, 
but computed tomography (CT) is much more sensitive. Laboratory tests show an elevated level of inflammatory markers.

Demonstrating SARS-CoV-2 RNA. The virus RNA can be demonstrated by real-time reverse-transcriptase polymerase chain reaction (RT-PCR). Throat swab samples or deep nasal cavity swab samples are required for the test. Taking the sample properly is very important; it should be a deep wipe, and the person taking the sample should wear completely protective garments. The positive predictive value of the test is very high. On the other hand, a negative result does not rule out SARS-CoV-2 infection: negativity can be the consequence of bad sampling, or other methodological problems, low virus concentration in the nasal mucosa (mainly in the first few days after infection), or when the virus has already moved into the lower respiratory tract. While a positive is usually considered an indicator of COVID-19 and isolation, a subsequent negative should be followed by discharge or transfer of the patient only with caution. Testers should make such a decision by taking to account several factors [19]. In the stage of viremia, a blood sample is also an appropriate test. SARS-CoV RNA was detected in $50 \%$ of the plasma and $78 \%$ of serum samples during the first week of illness [20]. The drawback of RTPCR is time-consuming, requires sophisticated equipment, and it is expensive. The relatively high rate of false-negative results is also a problem. In any case, SARS-CoV-2 RT-PCR plays an essential role in diagnosis and should be strictly standardized.

Serological tests. IgM and IgG antibodies produced against SARS-CoV-2 can be demonstrated from the blood. Production of antibodies is a process requiring 7-10 days after infection. First IgM antibodies are produced, then IgG antibodies are produced by B-lymphocytes. It has been demonstrated that high levels of IgM antibodies can be found 5 days after the onset of illness - not only in patients with clinical symptoms but also in asymptomatic patients. Thus, it was proposed that PCR testing should be combined with and IgM ELISA assay for enhanced sensitivity [21]. More evidence is needed to confirm the IgM and IgG kinetics of SARS-CoV-2. The adequate interpretation of results is very important: the presence of antibodies may not mean an acute infection, but rather a recent infection. It may also suggest that the patient has a defence against repeated SARS-CoV-2 infection, but that is still a matter of debate. Though antibody seroconversion provides reliable proof of former infection, serological tests are not suitable for early diagnosis [22]. Among the serological assays, enzyme-linked immunosorbent assay (ELISA) and chemiluminescence assay (CLIA) are suitable for first-line screening because of the large throughput, short processing time, and simple procedure [23].

Clinical symptoms. While most patients experience no or very mild symptoms, about $14 \%$ of COVID-19 patients with respiratory symptoms require supplemental oxygen, and approximately $5 \%$ develop a need for mechanical ventilation
[24]. ARDS was observed to develop in $17-29 \%$ of hospitalized patients approximately 8 days after symptoms onset [25].

The most frequent symptoms are fever (88.5\%), cough (68.6\%), myalgia or fatigue $(35.8 \%)$, expectoration $(28.2 \%)$, and dyspnoea (21.9\%) [26]. Minor symptoms include headache or dizziness (12.1\%), diarrhoea (4.8\%), nausea, and vomiting (3.9\%). A special early symptom is the loss of taste and smell [24]. 'Silent hypoxaemia' has also been reported [27]. That means the development of respiratory failure without a subjective perception of the difficulty of breathing. Hypocapnia is a characteristic feature of 'silent hypoxaemia' because of compensatory hyperventilation. The characteristic symptoms that appear during a viral infection, such as running nose and sore throat, may be present, but less frequently than in influenza.

COVID-19 is more common in men than women: men account for 60 per cent of the cases [26].

The mortality rate of COVID-19 is thought to be around $5 \%$ [25]. This rate is much higher (14.8\%) in patients over 80 years of age and even higher (49\%) among the critically ill requiring mechanical ventilation [28]. It is not easy to determine the exact mortality rate because of the high number of patients with no or mild symptoms, meaning that the total number of SARS-CoV-2 infected people is underestimated. In those countries where few screening tests are performed, the mortality rate would be incorrectly considered high. The mortality rate is much higher in pneumonia patients superinfected with bacteria [29]. Advanced age ( $>60$ years), cancer, ischaemic heart disease, hypertension, diabetes mellitus, chronic lung disease, or major infections also increase the mortality.

Smoking also can be considered a risk factor for more serious symptoms and greater mortality. According to the study of Guan et al., there were higher percentages of smokers among patients that needed ICU support, mechanical ventilation, or who had died [30].

The main causes of mortality are acute respiratory distress syndrome (ARDS), sepsis, acute cardiac injury, acute kidney injury, multi-organ failure, and disseminated intravascular coagulopathy. Alkalosis, hyperkalemia, and hypoxic encephalopathy are also more common in deceased than in recovered patients [31].

Radiography. A chest CT scan may be useful for the rapid and early diagnosis of COVID-19. The sensitivity of a conventional chest $\mathrm{x}$-ray is $59 \%$, while that of CT is $98 \%$ [32]. CT findings may precede laboratory results by as many as 3 days [33]. However, CT findings of COVID-19 may overlap with other viruses, so CT is not suitable to distinguish between virus infections. Because of its high sensitivity, chest CT is very helpful not only for the early diagnosis of COVID-19 pneumonia but also for controlling disease progression and the efficacy of treatment.

Common CT features of COVID-19 are ground-glass opacities and consolidation (with or without vascular enlargement), interlobular septal thickening, crazy-paving pattern, and air bronchogram signs [33]. Lesions present on CT images have a peripheral distribution and bilateral 
involvement; they are lower lung predominant and multifocal [34]. The ventral area of the lung is frequently spared, which is why lying face down is favourable for these patients.

CT can also help identify patients in need of emergency care. Architectural distortion, traction bronchiectasis, pleural effusions, and diffuse legions are proportional to the viral load and virulence of COVID-19 and have a higher incidence in emergency patients [34].

CT-revealed abnormalities of COVID-19 pneumonia and the presence of clinical symptoms were evaluated by $\mathrm{Wu}$ and his colleagues. They found that COVID-19 clinical symptoms are milder while pulmonary changes revealed by CT are more severe than in other types of pneumonia [35].

Currently, the radiological strategy remains undefined. CT scanning should be reserved for patients with an undefined clinical picture, as well as for some types of differential diagnosis.

Laboratory examinations. Typical laboratory abnormalities are leukocytopenia, lymphocytopenia, increase of C-reactive protein, and lactic dehydrogenase [31]. Serum level of proinflammatory cytokines, serum ferritin, and D-Dimer are also characteristic findings [36]. An elevated troponin level may predict fulminant myocarditis. Troponin appears to be a strong prognostic indicator of mortality [37,38], as well as an elevated plasminogen level and thrombocytopaenia [39].

\section{Treatment}

Patients with mild COVID-19 symptoms recover on their own, but for others, there are no approved therapeutics or vaccines. There are drugs with a broad antiviral effect, however, that were registered originally for other diseases that appear to be effective against SARS-CoV-2 and are being used off-label. Hydroxychloroquine and chloroquine are effective in vivo against COVID-19. Angiotensin-converting enzyme inhibitors (ACEI) and angiotensin receptor blockers (ARB) may also have some prophylactic effect. There are some promising results with passive immunization with sera of recovered COVID-19 patients. The mainstream treatment is supportive therapy. There are ongoing trials for several COVID-19 treatments. A great number of new compounds are being tested, and some registered drugs are being considered as candidates for repurposing [40]. There are two main classes of drugs: compounds that directly inhibit the replication cycle of the virus, and those that boost innate antiviral immune responses or diminish the cytokine storm induced by the infection [40]. Development of a vaccine capable of active immunization is also under way, but testing for safety and efficacy is a long process.

In the current circumstances, prevention is extremely important. Governments have to fine-tune between restrictive measures and maintaining the economy and ensuring that people have a viable life. The main goal is to keep the number of patients at a manageable level.

\section{Preventive measures}

The most important rules to prevent being infected are keeping a social distance of $1.5-2 \mathrm{~m}$, wearing a mask which can screen small particles, and frequent hand washing or disinfection. Using soap is appropriate, as it can remove the lipid-soluble virus. Shaking hands and hugging should be avoided. The elderly and those with chronic diseases should be more careful. They should stay home and ask for help in managing their shopping and business affairs. For healthcare workers, it is compulsory to wear protective clothing during patient care and to submit to frequent screening for SARS-CoV-2 infection. Screening is also important for patients who are admitted to a hospital. The patient should be separated until the result is known. If it is positive, a 14-day quarantine is required. It can be a home quarantine or in the hospital if required by the home circumstances or the symptoms.

Antiviral drugs. The antiviral prodrugs favipiravir, geldesivir, ribavirin, and remdesivir are nucleoside analogues. Remdesivir was tested against Ebola and Marburg virus infections without success, but it is a promising therapy for COVID-19. As its structure resembles adenosine, it inhibits viral RNA-dependent RNA polymerase by substituting itself for adenosine during RNA synthesis [41]. It is administered intravenously. The first successful remdesivir therapy in a COVID-19 patient was in January 2020 [42]. Since then, remdesivir has been administered on a compassionate use basis to severely ill patients requiring mechanical ventilation. It has significantly reduced mortality [43]. It should be remembered, however, that there are currently no antiviral drugs proven to be effective against COVID- 19 .

Hydoxycloroquine, chloroquine. The antiviral activity of chloroquine was already identified in the late 1960s [44]. Hydroxychloroquine and chloroquine have recently been reported to have antiviral efficacy against SARS-CoV-2 [45]. Phosphate and sulphate derivatives of chloroquine have been used for decades as an antimalarial agent, while hydroxychloroquine is an immunomodulatory agent widely used for several systemic autoimmune diseases such as systemic lupus erythematodes. The United States Food and Drug Administration (FDA) has provided emergency authorization for the use of chloroquine and hydroxychloroquine for COVID-19 patients [46]. These drugs are frequently combined with the macrolide antibiotic, azithromycin. Being a weak base, hydroxychloroquine accumulates in the acid environment of endolysosomes and other acidic cell organelles and interferes with virus binding [47]. Hydroxychloroquine also has antithrombotic effects, which may favourably interfere with the activated coagulation and microthrombus formation in COVID-19 disease [48]. Chloroquine and hydroxychloroquine have a narrow therapeutic range, meaning that the window between therapeutic and toxic doses is narrow. They, therefore, may easily cause serious toxicity, resulting in a conduction defect (a prolongation of the $\mathrm{QT}_{\mathrm{c}}$ interval, which may lead to torsade de pointes, a polymorphic ventricular tachyarrhythmia), ventricular arrhythmias, cardiomyopathy, and retinopathy such as bull's eye phenomenon, which causes irreversible damage of the macular tissue, visual 
deterioration, and severe dyschromatopsia [49]. Because of the high frequency of ventricular arrhythmias, the ECG of patients treated with chloroquine and hydroxychloroquine should be monitored. A synergistic effect of azithromycin and hydroxychloroquine has also been suggested [50]. The real efficacy of hydroxychloroquine has not been established yet, as the largest study to date found no benefit, and increased mortality risk [51].

Role of angiotensin-converting enzyme inhibitors (ACEI) and angiotensin receptor blockers (ARB). ACEI and ARB are anti-hypertensive drugs given to patients with heart failure and coronary heart disease. For patients with type 2 diabetes mellitus with these indications, they are the drugs of choice. Though at first ACEI and ARB were thought to worsen COVID-19, it has been revealed that they have a beneficial effect [52] by inducing ACE2 receptor blockade and disabling viral entry into the heart and lungs, thereby causing an overall decrease of inflammation. Despite the contradictory hypotheses, cardiology associations strongly recommend continuing treatment with ACEI or ARB in patients who were previously taking either class of medication [53].

Passive immunization. The humoural immune response mediated by antibodies is crucial for preventing viral infections. In active immunization, specific antibodies are generated against viral antigens by B-lymphocytes. Binding of these antibodies to the pathogen antigens antagonizes their interaction with a cell receptor, and they are therefore called neutralizing antibodies. Since vaccines for active immunization have not yet been developed COVID-19 patients may benefit from passive immunization. The plasma of patients who have recovered from COVID-19 contains IgM and IgG immunoglobulins generated against SARS-CoV-2 antigens. These antibodies can be collected as convalescent plasma and transferred by an intravenous injection to a COVID-19 patient, where they can neutralize the pathogen, boost the immunity, and help the patient fight off the disease [54].

Development of a vaccine. Several pharmaceutical companies are developing vaccines, but it is estimated that it will take months to years before they are available for sale.

Phase I and II clinical trials are underway with an inactivated vaccine generated from a patient-derived SARS$\mathrm{CoV}-2$ isolate. The efficacy of the vaccine has been proven on non-human primates. Rhesus macaques were immunized with the vaccine plus alum, then challenged with a virus from a different isolate. Vaccinated macaques had no symptoms and a rapid decrease in viral loads. Yet, there is a long way to find an adequate dose and to prove the vaccine's safety [55].

Possible targets for anti-COVID-19 drugs. There are two main approaches to drug development. One is to target the virus itself, and the other is to control the immune system of the host. One possible approach is to target ACE2-spike protein interaction with selective antibodies. Antibodies directed against ACE2 are demonstrated to reduce SARS-
CoV-2 virus entry into target cells [56]. Weak bases such as ammonium chloride and chloroquine can accumulate in acidified lysosome-like vesicles, play a role in viral uncoating, and thus, in the inhibition of viral replication. Other potential mechanisms of action may be the inhibition of virus replication by blocking viral RNA translation, the inhibition of nucleotide turnover, and the action of viral proteinases [57].

Inhibition of inflammation. COVID-19 pneumonia is characterized in a subset of patients by a severe systemic inflammation reaction, called a cytokine storm. An elevated serum level of IL- 6 and ferritin is considered a predictor for COVID-19-related mortality, suggesting that hyper inflammation increases the risk of mortality (2). Drugs with an immunomodulatory property may mitigate the virusinduced cytokine storm and limit lung damage in patients with severe disease [58].

Several questions arise concerning the application of anti-inflammatory drugs: when to give them, to whom, and for how long? Which one is the best choice? A drug with a very selective action or a wider one? Some of these drugs, e.g., Janus kinase (JAK) inhibitors, also block interferon- $\alpha$ production, which is important in fighting the virus. Would they do more harm than good? Further studies are needed to answer these questions.

Tocilizumab is a humanized interleukin-6 receptor antagonist that was approved to treat patients with rheumatoid arthritis. Decrease of body temperature and a decrease of oxygen demand were detected in those severe or critical COVID-19 patients who received tocilizumab in a non-randomized Chinese trial [59].

Baricitinib, a JAK inhibitor as well as an AAK1 (AP2associated protein kinase 1) inhibitor, is also a potential candidate for COVID-19 therapy, considering its relative safety and high affinity. However, it might be a problem that JAK inhibitors can inhibit a variety of inflammatory cytokines, including INF-a, which have a beneficial role in controlling virus activity.

Baricitinib is more effective when used in combination with anti-viral drugs like Remidesivir [60].

Supportive therapy. The mainstay of COVID-19 management is supportive care consisting of symptomatic therapy (antipyretics, antibiotics, parenteral feeding, and fluid replacement) and respiratory support.

Oxygen therapy should be given to patients with hypoxemia. If standard oxygen therapy fails, mechanical ventilation should be applied; high flow nasal catheter oxygen or the bi-level positive airway pressure mode can be used. If there is no improvement, invasive mechanical ventilation should be applied (31). For patients with refractory hypoxemia, extracorporeal membrane oxygenation (ECMO) is advised [61].

Patients with cardiovascular diseases are prone to having more serious COVID-19 symptoms. Supportive treatment of these patients may include anticoagulation, a continuation of renin-angiotensin-aldosterone system inhibitor treatment, 
arrhythmia monitoring, and mechanical circulatory support [61].

In the case of concurrent bacterial pneumonia, the application of an antibiotic is recommended. However, the routine use of antibiotics is not advised.

\section{Ophthalmological aspects}

As it is known the Coronavirus-19 travels and infects through droplets in the air, sneezing, coughing, or speaking might be the route of infection. It is strongly suspected that the virus can also be transmitted through the eyes. The danger of being infected through the eyes is relatively low compared to breathing the droplets, but eye protection with special plastic goggles is important against infection.

Ophthalmology had an early relevance in December 2019, when ophthalmologist Li Weinlang discovered and reported to his previous classmates the new disease in Wuhan. He found special symptoms among his glaucoma and cataract patients: fatigue, coughing, sneezing, and pneumonia. Later he also got the COVID-19 infection and died in the Intensive Care Unit of Wuhan (Coronavirus kills Chinese whistle blower ophthalmologist BBC, CNN 10th $\mathrm{Feb} / 2020)$. Later, he became a national hero in China.

In 2003, when the SARS outbreak first happened, it was presumed that the virus entered the body through ACE2 receptors. They are widely found in the body, in the heart, kidney, intestines, and lungs. They can also be found in the retina and in mucous membranes like the conjunctiva. The virus presumably mimics the shape of ACE2 enzyme, so the affected cells allow the virus to enter. Once the virus is in the cell, it replicates until the cell membrane ruptures. In the eye, the virus may cause conjunctivitis, chemosis, and epiphora (tearing). Since COVID-19 positive patients may show ophthalmic symptoms, some precautions are recommended: switching from contact lenses to spectacles to prevent direct contact with the eye, not rubbing the eyes, wearing glasses or sunglasses, washing hands frequently, not touching the face, not shaking hands, wearing a mask in public, and keeping social distance. Although eye symptoms vary between serious COVID-19 patients, the virus can be isolated from the tear; therefore, eye protection is of utmost importance especially for personnel taking care of ophthalmic patients.

\section{Hungarian aspects}

In Hungary, the epidemic was successfully curbed owing to the quick and early governmental interventions. At the time this manuscript was submitted, there had been 3713 COVID-19 cases, including 482 deaths and 1,576 patients with the active disease reported. According to a representative survey conducted by the four Hungarian medical universities, with the leadership of the Semmelweis University, the frequency of SARS-CoV-2 positivity among the Hungarian population was $0.02 \%$, and the IgG positivity varied between 0.6 and $0.8 \%$. Passive immunization with sera of convalescent patients was successfully carried out on three severely ill patients. Development of a vaccine has also been started at the University of Debrecen Medical and
Health Science Center. It is hoped that small-scale manufacturing will begin in October. Now, as the epidemic is supposed to be in a declining phase, there is a cautious release of restrictive measures throughout the country, but the possible beginning of a second phase of the epidemic is carefully watched for.

\section{Recommendation}

We would like to end this review by quoting the opening remarks of the WHO Director-General at the meeting on $11^{\text {th }}$ of March when he announced COVID-19 to be a pandemic:

"This is not just a public health crisis. It is a crisis that will
touch every sector - so every sector and every individual
must be involved in the fight. ... strategy to prevent in-
fections, save lives, and minimize impact. ... Let me give you
some other words that matter much more, and that are
much more actionable. Prevention. Preparedness. Public
health. Political leadership. And most of all, people. We're in
this together, to do the right things with calm and protect the
citizens of the world. It's doable" [1].

We agree the world will overcome the crisis.

Authors' contribution: KG and GYD equally took part in writing the manuscript, ZZ Nagy wrote the ophthalmological part and took part in the correction of the manuscript.

Ethical approval: This review was conducted in accordance with the Declaration of Helsinki and according to requirements of all applicable local and international standards.

Conflicts of interest: No financial support was received for this study.

Acknowledgement: Authors have not received any grant or other financial support.

\section{REFERENCES}

1. WHO Director-General's opening remarks at the media briefing on COVID-19 - 11 March 2020. [Internet]. Geneva: World Health Organization; [cited 2020 May 20]. Available from: https://www. who.int/dg/speeches/detail/who-director-general-s-opening-remarksat-the-media-briefing-on-covid-19-11-march-2020.

2. Huang C, Wang Y, Li X, Ren L, Zhao J, Hu Y, et al. Clinical features of patients infected with 2019 novel coronavirus in Wuhan, China. Lancet. 2020;395(10223):497-506. https://doi.org/10.1016/S01406736(20)30183-5.

3. Bogoch II, Watts A, Thomas-Bachli A, Huber C, Kraemer MUG, Khan K. Pneumonia of unknown aetiology in Wuhan, China: potential for international spread via commercial air travel. J Travel Med 2020;27(2):taaa008. https://doi.org/10.1093/jtm/taaa008.

4. Worldometer. [Internet]. COVID-19 Coronavirus pandemic. [cited 2020 May 20]. Available from: https://www.worldometers.info/ coronavirus/. 
5. Chen N, Zhou M, Dong X, Qu J, Gong F, Han Y, et al. Epidemiological and clinical characteristics of 99 cases of 2019 novel coronavirus pneumonia in Wuhan. China: a descriptive study. Lancet 2020; 395(10223):507-13. https://doi.org/10.1016/S0140-6736(20)30211-7.

6. Zhang T, Wu Q, Zhang Z. Probable Pangolin Origin of SARS-CoV2 Associated with the COVID-19 Outbreak. Curr Biol 2020;30(7): 1346-51.e2. https://doi.org/10.1016/j.cub.2020.03.022.

7. Rothan HA, Byrareddy SN. The epidemiology and pathogenesis of coronavirus disease (COVID-19) outbreak. J Autoimmun 2020;109: 102433. https://doi.org/10.1016/j.jaut.2020.102433.

8. Walls AC, Park YJ, Tortorici MA, Wall A, McGuire AT, Veesler D. Structure, function, and antigenicity of the SARS-CoV-2 spike glycoprotein. Cell 2020;181(2):281-92.e6. https://doi.org/10.1016/j. cell.2020.02.058.

9. Kuba K, Imai Y, Ohto-Nakanishi T, Penninger JM. Trilogy of ACE2: a peptidase in the renin-angiotensin system, a SARS receptor, and a partner for amino acid transporters. Pharmacol Ther 2010;128(1): 119-28. https://doi.org/10.1016/j.pharmthera.2010.06.003.

10. Yan T, Xiao R, Lin G. Angiotensin-converting enzyme 2 in severe acute respiratory syndrome coronavirus and SARS-CoV-2: A double-edged sword?. FASEB J 2020;34(5):6017-26. https://doi.org/ 10.1096/fj.202000782.

11. Hamming I, Timens W, Bulthuis ML, Lely AT, Navis G, van Goor H. Tissue distribution of ACE2 protein, the functional receptor for SARS coronavirus. A first step in understanding SARS pathogenesis. J Pathol 2004;203(2):631-7. https://doi.org/10.1002/path.1570.

12. Li W, Moore MJ, Vasilieva N, Sui J, Wong SK, Berne MA, et al. Angiotensin-converting enzyme 2 is a functional receptor for the SARS coronavirus. Nature 2003;426(6965):450-4. https://doi.org/ 10.1038/nature02145.

13. Xu Z, Shi L, Wang Y, Zhang J, Huang L, Zhang C, et al. Pathological findings of COVID-19 associated with acute respiratory distress syndrome. Lancet Respir Med 2020;8(4):420-2. https://doi. org/10.1016/S2213-2600(20)30076-X.

14. Karami P, Naghavi M, Feyzi A, Aghamohammadi M, Novin MS, Mobaien A, et al. WITHDRAWN: Mortality of a pregnant patient diagnosed with COVID-19: A case report with clinical, radiological, and histopathological findings. Travel Med Infect Dis 2020;101665. https://doi.org/10.1016/j.tmaid.2020.101665.

15. Zhang W, Zhao Y, Zhang F, Wang Q, Li T, Liu Z, et al. The use of anti-inflammatory drugs in the treatment of people with severe coronavirus disease 2019 (COVID-19): The Perspectives of clinical immunologists from China. Clin Immunol 2020;214:108393. https://doi.org/10.1016/j.clim.2020.108393.

16. van Doremalen N, Bushmaker T, Morris DH, Holbrook MG, Gamble A, Williamson BN, et al. Aerosol and surface stability of SARS-CoV-2 as compared with SARS-CoV-1. N Engl J Med 2020; 382(16):1564-7. https://doi.org/10.1056/NEJMc2004973.

17. Remais J. Modelling environmentally-mediated infectious diseases of humans: transmission dynamics of schistosomiasis in China. Adv Exp Med Biol 2010;673:79-98. https://doi.org/10.1007/978-14419-6064-1_6.

18. Frieden TR, Lee CT. Identifying and interrupting superspreading events-implications for control of severe acute respiratory syndrome coronavirus 2. Emerg Infect Dis 2020;26(6):1059-66. https:// doi.org/10.3201/eid2606.200495.

19. Xiao A, Tong Y, Zhang S. False negative of RT-PCR and prolonged nucleic acid conversion in COVID-19: Rather than recurrence. J Med Virol 2020;92:1755-6. https://doi.org/10.1002/jmv.25855.
20. Ng EK, Hui DS, Chan KC, Hung EC, Chiu RW, Lee N, et al. Quantitative analysis and prognostic implication of SARS coronavirus RNA in the plasma and serum of patients with severe acute respiratory syndrome. Clin Chem 2003;49(12):1976-80. https://doi. org/10.1373/clinchem.2003.024125.

21. Guo L, Ren L, Yang S, Xiao M, Chang D, Yang F, et al. Profiling early humoral response to diagnose novel coronavirus disease (COVID-19). Clin Infect Dis. 2020;ciaa310. https://doi.org/10.1093/cid/ciaa310.

22. Yan Y, Chang L, Wang L. Laboratory testing of SARS-CoV, MERS$\mathrm{CoV}$, and SARS-CoV-2 (2019-nCoV): Current status, challenges, and countermeasures. Rev Med Virol 2020;30(3):e2106. https://doi. org/10.1002/rmv.2106.

23. Zhang W, Du RH, Li B, Zheng XS, Yang XL, Hu B, et al. Molecular and serological investigation of $2019-\mathrm{nCoV}$ infected patients: implication of multiple shedding routes. Emerg Microbes Infect. 2020;9(1):386-9. https://doi.org/10.1080/22221751.2020.1729071.

24. Guan WJ, Ni ZY, Hu Y, Liang WH, Ou CQ, He JX, et al. Clinical characteristics of coronavirus disease 2019 in China. N Engl J Med 2020;382(18):1708-20. https://doi.org/10.1056/NEJMoa2002032.

25. Wang D, Hu B, Hu C, Zhu F, Liu X, Zhang J, et al. Clinical characteristics of 138 hospitalized patients with 2019 novel coronavirus-infected pneumonia in Wuhan, China. JAMA 2020; 323(11):1061-9. https://doi.org/10.1001/jama.2020.1585.

26. Li LQ, Huang T, Wang YQ, et al. COVID-19 patients' clinical characteristics, discharge rate, and fatality rate of meta-analysis. J Med Virol 2020;92(6):577-83. https://doi.org/10.1002/jmv.25757.

27. Xie J, Tong Z, Guan X, Du B, Qiu H, Slutsky AS. Critical care crisis and some recommendations during the COVID-19 epidemic in China. Intensive Care Med. 2020;46(5):837-40. https://doi.org/10. 1007/s00134-020-05979-7.

28. Wu Z, McGoogan JM. Characteristics of and Important Lessons From the Coronavirus Disease 2019 (COVID-19) Outbreak in China: Summary of a Report of 72314 Cases From the Chinese Center for Disease Control and Prevention. JAMA 2020;10.1001/ jama.2020.2648. https://doi.org/10.1001/jama.2020.2648.

29. Kui L, Fang YY, Deng Y, Liu W, Wang MF, Ma JP, et al. Clinical characteristics of novel coronavirus cases in tertiary hospitals in Hubei Province. Chin Med J 2020;133(9):1025-31. https://doi.org/ 10.1097/CM9.0000000000000744.

30. Chen T, Wu D, Chen H, Yan W, Yang D, Chen G, et al. Clinical characteristics of 113 deceased patients with coronavirus disease 2019: retrospective study. BMJ 2020;368:m1091. https://doi.org/10. 1136/bmj.m1091.

31. Fang Y, Zhang H, Xie J, Lin M, Ying L, Pang P, et al. Sensitivity of chest CT for COVID-19: comparison to RT-PCR. Radiology 2020; 200432. https://doi.org/10.1148/radiol.2020200432.

32. Li Y, Xia L. Coronavirus disease 2019 (COVID-19): role of chest CT in diagnosis and management. AJR Am J Roentgenol 2020;214(6): 1280-6. https://doi.org/10.2214/AJR.20.22954.

33. Zhao W, Zhong Z, Xie X, Yu Q, Liu J. Relation between chest CT findings and clinical conditions of coronavirus disease (COVID-19) pneumonia: a multicenter study. AJR Am J Roentgenol 2020; 214(5):1072-7. https://doi.org/10.2214/AJR.20.22976.

34. Wu J, Wu X, Zeng W, Guo D, Fang Z, Chen L, et al. Chest CT findings in patients with coronavirus disease 2019 and its relationship with clinical features. Invest Radiol 2020;55(5):257-61. https://doi.org/10.1097/RLI.0000000000000670.

35. Zhang J, Liu P, Wang M, Wang J, Chen J, Yuan W, et al. The clinical data from 19 critically ill patients with coronavirus disease 2019: a 
single-centered, retrospective, observational study. Z Gesundh Wiss 2020:1-4. https://doi.org/10.1007/s10389-020-01291-2.

36. Driggin E, Madhavan MV, Bikdeli B, Chuich T, Laracy J, BiondiZoccai G, et al. Cardiovascular considerations for patients, health care workers, and health systems during the COVID-19 pandemic. J Am Coll Cardiol 2020;75(18): 2352-71. https://doi.org/10.1016/j. jacc.2020.03.031.

37. Vrsalovic M, Vrsalovic Presecki A. Cardiac troponins predict mortality in patients with COVID-19: A meta-analysis of adjusted risk estimates. J Infect. 2020;S0163-4453(20)30300-5. https://doi. org/10.1016/j.jinf.2020.05.022.

38. Liu Y, Sun W, Guo Y, Chuich T, Laracy J, Biondi-Zoccai G, et al. Association between platelet parameters and mortality in coronavirus disease 2019: Retrospective cohort study. Platelets 2020;31(4): 490-6. https://doi.org/10.1080/09537104.2020.1754383.

39. Tu YF, Chien CS, Yarmishyn AA, Lin YY, Luo YH, Lin YT, et al. A review of SARS-CoV-2 and the ongoing clinical trials. Int J Mol Sci 2020;21(7):2657. https://doi.org/10.3390/ijms21072657.

40. Gordon CJ, Tchesnokov EP, Feng JY, Porter DP, Götte M. The antiviral compound remdesivir potently inhibits RNA-dependent RNA polymerase from Middle East respiratory syndrome coronavirus. J Biol Chem 2020;295(15): 4773-9. https://doi.org/10.1074/ jbc.AC120.013056.

41. Holshue M L, DeBolt C, Lindquist S, Lofy KH, Wiesman J, Bruce H, et al. First Case of 2019 Novel Coronavirus in the United States. N Engl J Med. 2020;382(10):929-36. https://doi.org/10.1056/NEJMoa2001191.

42. Grein J, Ohmagari N, Shin D, Diaz G, Asperges E, Castagna A, et al. Compassionate use of Remdesivir for patients with severe covid-19. $\mathrm{N}$ Engl J Med 2020;382(24):2327-36. https://doi.org/10.1056/ NEJMoa2007016.

43. Touret F, de Lamballerie X. Of chloroquine and COVID-19. Antiviral Res 2020;177:104762. https://doi.org/10.1016/j.antiviral.2020.104762.

44. Yan Y, Zou Z, Sun Y, Li X, Xu KF, Wei Y, et al. Anti-malaria drug chloroquine is highly effective in treating avian influenza A H5N1 virus infection in an animal model. Cell Res. 2013;23(2):300-2. https://doi.org/10.1038/cr.2012.165.

45. Wang M, Cao R, Zhang L, Yang X, Liu J, Xu M, et al. Remdesivir and chloroquine effectively inhibit the recently emerged novel coronavirus (2019-nCoV) in vitro. Cell Res 2020;30(3):269-71. https://doi.org/10.1038/s41422-020-0282-0.

46. Vincent MJ, Bergeron E, Benjannet S, Erickson BR, Rollin PE, Ksiazek TG, et al. Chloroquine is a potent inhibitor of SARS coronavirus infection and spread. Virol J 2005;2:69. https://doi.org/ 10.1186/1743-422X-2-69.

47. Nosál R, Jancinová V. Cationic amphiphilic drugs and platelet phospholipase A(2) (cPLA(2)).Thromb Res 2002;105(4):339-45. https://doi.org/10.1016/s0049-3848(02)00036-1.

48. Chatre C, Roubille F, Vernhet H, Jorgensen C, Pers YM. Cardiac complications attributed to chloroquine and hydroxychloroquine: a systematic review of the literature. Drug Saf 2018;41(10):919-31. https://doi.org/10.1007/s40264-018-0689-4.

49. Delang L, Neyts J. Medical treatment options for COVID-19. Eur Heart J Acute Cardiovasc Care 2020;9(3):209-14. https://doi.org/ $10.1177 / 2048872620922790$.
50. Magagnoli J, Narendran S, Pereira F, Cummings T, Hardin JW, Sutton SS, et al. Outcomes of Hydroxychloroquine usage in United States veterans hospitalized with COVID-19. Preprint. medRxiv 2020; 2020.04.16.20065920. https://doi.org/10.1101/2020.04.16.20065920.

51. Meng J, Xiao G, Zhang J, He X, Ou M, Bi J, et al. Renin-angiotensin system inhibitors improve the clinical outcomes of COVID-19 patients with hypertension. Emerg Microbes Infect 2020;9(1): 757-60. https://doi.org/10.1080/22221751.2020.1746200.

52. Statement from the American Heart Association, the Heart Failure Society of America and the American College of Cardiology. [Internet]. Patients taking ACE-i and ARBs who contract COVID19 should continue treatment, unless otherwise advised by their physician. [cited 2020 May 20]. Available from: https://newsroom. heart.org/news/patients-taking-ace-i-and-arbs-who-contract-covid19-should-continue-treatment-unless-otherwise-advised-by-theirphysician.

53. Marano G, Vaglio S, Pupella S, Facco G, Catalano L, Liumbruno GM, et al. Convalescent plasma: New evidence for an old therapeutic tool?. Blood Transfusion 2016;14(2):152-7. https://doi.org/ 10.2450/2015.0131-15.

54. Gao Q, Bao L, Mao H, Wang L, Xu K, Yang M, et al. Rapid development of an inactivated vaccine candidate for SARS-CoV-2. Science 2020;eabc1932. https://doi.org/10.1126/science.abc1932.

55. Hoffmann M, Kleine-Weber H, Schroeder S, Krüger N, Herrler T, Erichsen S, et al. SARS-CoV-2 cell entry depends on ACE2 and TMPRSS 2 and is blocked by a clinically proven protease inhibitor. Cell 2020;181(12): 271-80.e8. https://doi.org/10.1016/j.cell.2020.02.052.

56. Alexander SPH, Armstrong J, Davenport AP, Davies J, Faccenda E, Harding SD, et al. A rational roadmap for SARS-CoV-2/COVID-19 pharmacotherapeutic research and development. IUPHAR Review 29. Br J Pharmacol 2020;10.1111/bph.15094. https://doi.org/10. 1111/bph.15094.

57. Sanofi U.S. [Internet]. Sanofi and Regeneron provide update on U.S. Phase $2 / 3$ adaptive-designed trial in hospitalized COVID-19 patients. [cited 2020 Apr 29]. Available from: http://www.news. sanofi.us/April-27-2020-Sanofi-and-Regeneron-provide-updateon-U-S-Phase-2-3-adaptive-designed-trial-in-hospitalizedCOVID-19-patients.

58. Fu B, Xu X, Wei H. Why tocilizumab could be an effective treatment for severe COVID-19. J Transl Med 2020;18(1):164. https:// doi.org/10.1186/s12967-020-02339-3.

59. Stebbing J, Phelan A, Griffin I, Tucker C, Oechsle O, Smith D, et al. COVID-19: combining antiviral and anti-inflammatory treatments. Lancet Infect Dis 2020;20(4):400-2. https://doi.org/10.1016/S14733099(20)30132-8.

60. WHO. [Internet]. Clinical management of severe acute respiratory infection (SARI) when novel coronavirus (nCoV) infection is suspected. Geneva: World Health Organization; [cited 2020 March 13]. Available from: https://www.who.int/docs/default-source/coronaviruse/ clinical-management-of-novel-cov.pdf?sfvrsn=bc7da517_2.

61. Kang Y, Chen T, Mui D, Ferrari V, Jagasia D, Scherrer-Crosbie M, et al. Cardiovascular manifestations and treatment considerations in covid-19. Heart 2020; heartjnl-2020-317056. https://doi.org/10. 1136/heartjnl-2020-317056.

Open Access. This is an open-access article distributed under the terms of the Creative Commons Attribution 4.0 International License (https://creativecommons.org/ licenses/by/4.0/), which permits unrestricted use, distribution, and reproduction in any medium, provided the original author and source are credited, a link to the CC License is provided, and changes - if any - are indicated. (SID_1) 